\title{
ANALYSIS OF LEAD ADSORPTION IN OXISOLS AND EVALUATION OF ITS PHYTOAVAILABILITY
}

\author{
P. R. FRADE ${ }^{1}$, L. R. de OLIVEIRA ${ }^{2}$, C. C. de AMORIM ${ }^{1}$, M. M. D. LEÃO ${ }^{1}$ e E. O. NETO ${ }^{3}$ \\ ${ }^{1}$ Universidade Federal de Minas Gerais, Departamento de Engenharia Sanitária e Ambiental \\ ${ }^{2}$ Centro Universitário de Formiga , Departamento de Engenharia Ambiental \\ ${ }^{3}$ Universidade Federal de Minas Gerais, Departamento de Engenharia Metalúrgica e de Materiais \\ E-mail para contato: paulorfrad@gmail.com
}

\begin{abstract}
Adsorption reactions in the mobility and availability of lead $(\mathrm{Pb})$ in soils and uptake by plants are important because of its potential for contamination of humans and animals. Considering the lack of information of this nature in variable charge soils, this paper aimed to study the chemical and physical properties of soils collected in five points the margin of a highway, analyze the reactions of these five soils and tomatoes (Lycopersicon esculentum) at different $\mathrm{pH}$ values and four concentrations of lead, applied in the form of nitrate, and to correlate the properties of the soil and the results obtained. We analyzed different chemical and physical properties of soils and the levels of lead, before and after 60 days to start the experiment. The soils under study were classified as medium texture and clayey and lead values found are within the range of natural levels in the soil. The interaction effects were only observed between the treatments containing higher doses of lead nitrate added and $\mathrm{pH}$ adjusted to 6.5. Samples of tomatoes were separated into aerial part and fruits and then analyzed for lead content. In tomato aerial part, the significant difference was only observed with the higher dose, whereas in the fruit $\mathrm{Pb}$ concentrations were below the detection limit.
\end{abstract}

\section{INTRODUCTION}

Lead $(\mathrm{Pb})$ is a heavy metal potentially toxic to humans and animals. Therefore, its use tends to be restricted in order to minimize the risks from their accumulation in soils, water and air. The increasing use of land transport powered by fossil fuels has caused a significant increase in environmental pollution on land areas adjacent to roads. During the road's cycle life are produced by the materials used to build it and the movement of vehicles, compounds that may contaminate the environment (ANDREOLI, 1998).

The final fate of heavy metals is its accommodation and infiltration in soils and sediments. Heavy metals are often accumulate in the top soil layer and are then accessible to the roots of plants. The soil has a great capacity to retain heavy metals, however, if this capacity is exceeded, the metal availability in the middle penetrate the food chain of living organisms or are leached, jeopardizing the quality of the groundwater system (PAOLIELLO; CHASIN, 2001). 


\section{9 a 22 de outubro de 2014 \\ Florianópolis/SC}

This food chain contamination is one of the important pathways for the entry of these toxic pollutants into the human body. Heavy metal accumulation in plant depend upon plant species and the efficiency of different plants depends is evaluated by either plant uptake or Soil to plant transfer factors of the metal (RATTAN et al., 2005).

Vegetables take up metals by absorbing them from contaminated soil as well as from deposits on different parts of the vegetables exposed to the air from polluted environments (SOBUKOLA et al., 2003). Vegetable plants growing on heavy metal contaminated medium can accumulate high concentrations of trace elements to cause serious health risk to consumers (LONG et al., 2010). $\mathrm{Pb}$ in its cationic form $\mathrm{Pb} 2+$ is absorbed by plants because of its similarity with metals essential transition, differing in respect to the translocation plants, due to their ease of forming complexes with high steric hindrance (SILVA et al. , 2007a, 2007b).

The retention of these metals in soil can occur in different forms, being regulated mainly by specific adsorption phenomena (forming inner sphere complex, which are covalent bonds) or nonspecific adsorption (resulting in outer sphere complex, which links are ionic) (MCBRIDE, 1989). The understanding of the processes of adsorption and desorption of metals are essential to the remediation of contaminated areas, as well as prevention of future contamination (RIBEIRO; MENEZES; MESQUITA, 2007).

Therefore, this study aimed to characterize the soils margins of a highway, located in the Brazil and the influence of four levels of lead and three different $\mathrm{pH}$ soil values. As a way to evaluate their phytoavailability, crops of tomatoes were planted in the soils under study.

\section{EXPERIMENTAL DEVELOPMENT}

\subsection{Methodology}

Samples of the surface layer $(0-20 \mathrm{~cm})$ of Oxisols were collected in five equidistant points (A, B, C, D and E), along Route MG-050, located in Minas Gerais State, Brazil, chosen based on economic importance and size of the catchment area. These samples came from areas not known to be subject to intentional contamination with lead. We analyzed the levels of phosphorus (P), potassium $\left(\mathrm{K}^{+}\right)$, calcium $\left(\mathrm{Ca}^{2+}\right)$, magnesium $\left(\mathrm{Mg}^{2+}\right)$, aluminum $\left(\mathrm{Al}^{3+}\right)$, potential acidity $(\mathrm{H}+\mathrm{Al})$, exchange capacity effective cation $(\mathrm{t})$, capacity cation exchange at $\mathrm{pH} 7.0(\mathrm{~T})$, percent aluminum saturation $(\mathrm{m} \%)$, percent base saturation $(\mathrm{V} \%)$, organic matter $(\mathrm{OM}), \mathrm{pH}$ (measured in water) and texture. All analyzes were done according to international methodologies (ANDERSON; INGRAM, 1993).

To evaluate the mechanism of specific adsorption on the retention of lead in these soils, we applied four doses $(0,50,100$ and $500 \mathrm{mg})$ of lead nitrate $\left(\mathrm{Pb}\left(\mathrm{NO}_{3}\right)_{2}\right)$ for each pound of soil from every point of sampling. As the $\mathrm{pH}$ and the time provided directly influence the availability of chemical elements, the experiments were conducted on three soil $\mathrm{pH}$ values (4.5, 5.5 and 6.5) previously adjusted with calcium hydroxide $\left(\mathrm{Ca}(\mathrm{OH})_{2}\right)$ or hydrochloric acid $(\mathrm{HCl})$. The research was conducted in a greenhouse, totaling 60 treatments, each one with $4.5 \mathrm{~kg}$ of soil in pots and placed in this location where the humidity was maintained at $60 \%$. Prior to the experiment and after 60 days of 

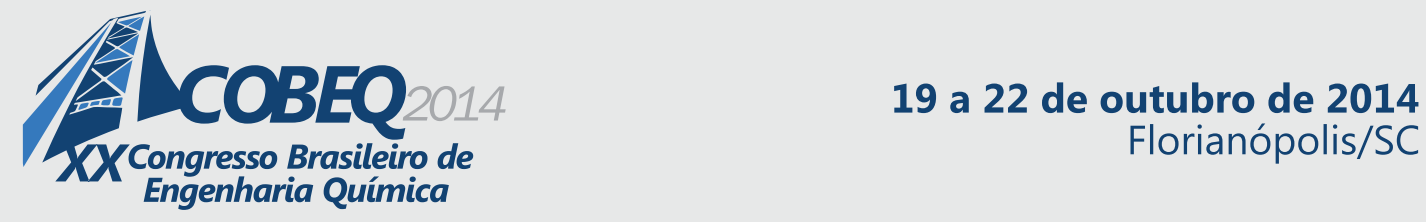

incubation, the samples were analyzed for soil determine the quantities of lead adsorbed, using USEPA 3051B method. This method use $1 \mathrm{~g}$ of soil digested with $10 \mathrm{~mL}$ of concentrated $\mathrm{HNO}_{3}$ in open block digester during 10 minutes at $95 \pm 5^{\circ} \mathrm{C}$. The samples were cooled and after the addition of another $5 \mathrm{~mL}$ of $\mathrm{HNO} 3$ again brought to the digester heating block at $95 \pm 5^{\circ} \mathrm{C}$ for 2 hours. They were then cooled and added to $2 \mathrm{~mL}$ of distilled water and $3 \mathrm{ml}$ of $\mathrm{H} 2 \mathrm{O} 2(30 \%)$. They were then conducted again to the block digester for another 2 hours at $95 \pm 5^{\circ} \mathrm{C}$. Subsequently, the samples were cooled and received $5 \mathrm{ml}$ of $\mathrm{HCl}$ and $10 \mathrm{ml}$ of distilled water were heated for 5 minutes at $95 \pm 5$ ${ }^{\circ} \mathrm{C}$. The aliquots were filtered and analyzed by atomic absorption spectrophotometer.

After the 60 days of incubation, seedling planting of tomatoes (Lycopersicon esculentum) was conducted in soils experiment. At the end of the crop cycle (90-100 days), the plants were harvested and separated into aerial part and fruit, and washed with deionized water. The aerial part was dried in an oven at a temperature between $65^{\circ}$ and $70^{\circ} \mathrm{C}$ until constant weight. For the determination of lead content, was made the nitropercloric digestion in the ratio 2:1 (v / v) of $\mathrm{HNO}_{3}$ and $\mathrm{HClO}_{4}$, for the dosage was used an atomic absorption spectrophotometer Varian with flame acetylene gas and lamps cathode hollow, at a wavelength 217 (nm) (MALAVOLTA; VITTI; OLIVEIRA, 1997). The fruits were washed in fresh running water to eliminate dusts, dirties, possible parasites or their eggs and were finally washed with deionized water. The clean vegetable samples were air-dried and placed in an electric oven at $65^{\circ} \mathrm{C}$ for $72-96 \mathrm{~h}$ depending on the sample size. The dry vegetable samples were homogenized by grinding using a ceramic coated grinder and used for metal analysis. One gram dry plant sample was weighed into 50-ml volumetric flask, followed by the addition of $10 \mathrm{ml}$ mixture of analytical grade acids $\mathrm{HNO}_{3}: \mathrm{HCIO}_{4}$ in the ratio 5:1. The digestion was performed at a temperature of about $190{ }^{\circ} \mathrm{C}$ for $1.5 \mathrm{~h}$. After cooling, the solution was made up to a final volume with distilled water. The metal concentrations were determined by atomic absorption spectrometry using a Atomic Absorption Spectrophotometer (AAS), model VARIAN (NASER et al., 2012). Finally, data were submitted to Tukey's statistical test using the SAS software.

\subsection{Results and Discussion}

The results of chemical analysis of soils and the total content of lead, before the start of the experiment are shown in Table 1.

Table 1: Chemical characterization and levels of lead in soil sampling points of the side of Route MG050

\begin{tabular}{|c|c|c|c|c|c|c|c|c|c|c|c|c|}
\hline \multirow{2}{*}{ Point } & \multirow{2}{*}{$\mathrm{pH}$} & $\mathrm{Ca}^{2+}$ & $\mathrm{Mg}^{2+}$ & $\mathrm{Al}^{3+}$ & $\mathrm{H}+\mathrm{Al}$ & $\mathrm{t}$ & $\mathrm{T}$ & $P$ & K & $\mathrm{Pb}$ & V & $\mathrm{m}$ \\
\hline & & \multicolumn{6}{|c|}{ - } & \multicolumn{2}{|c|}{$--m g d m^{-3}--$} & $\mathrm{mg} \mathrm{kg}^{-1}$ & \multicolumn{2}{|c|}{------\%------ } \\
\hline$A$ & 6.1 & 10.7 & 0.7 & 0.0 & 1.9 & 11.6 & 13.5 & 3.2 & 67 & 38.64 & 86.2 & 0.0 \\
\hline B & 6.2 & 2.9 & 1.3 & 0.0 & 2.3 & 4.4 & 6.7 & 1.1 & 73 & 29.18 & 65.3 & 0.0 \\
\hline C & 5.9 & 2.7 & 0.5 & 0.3 & 1.7 & 3.6 & 5.0 & 1.7 & 64 & 27.24 & 66.6 & 8.3 \\
\hline D & 6.1 & 5.1 & 1.1 & 0.0 & 2.1 & 6.4 & 8.5 & 3.2 & 92 & 36.44 & 75.6 & 0.0 \\
\hline E & 6.6 & 9.6 & 16.1 & 0.0 & 1.5 & 26.1 & 27.5 & 1.1 & 131 & 21.97 & 94.6 & 0.0 \\
\hline
\end{tabular}


Although Oxisols characterized by being acid soils, old, weathered, there were no detectable amounts of aluminum. Higher levels of $\mathrm{pH}$, calcium and magnesium can be explained by the soil sampling sites were close to areas of limestone mining. The lead content are found within the range of natural soil levels normally found between 10-100 $\mathrm{mg} \mathrm{kg}^{-1}$ (RIBEIRO; MENEZES; MESQUITA, 2007; ZINN; LAL; RESCK, 2005; OLIVEIRA, 2008).

The Figure 1 shows the texture analysis results. The soils of the points $\mathrm{B}, \mathrm{D}$ and $\mathrm{E}$ were classified as "medium textured" soils. The point C soil was classified as "sandy soil" and Point A soil as the "clayey soil". Oxisols represent about $45.7 \%$ of the Brazil soils and are described as highly weathered, deep, nonhydromorphic, high clay content (between 50 and 80\%) and low fertility (ZINN; LAL; RESCK, 2005). The differences in texture, possibly explain the natural contents of lead higher at Point A because the metal tends to adsorb this fraction of the soil. The clay influences the adsorption of metals due to the presence of oxides of $\mathrm{Fe}$ and $\mathrm{Al}$ (gibbsite, goethite, $\mathrm{Fe}$ and $\mathrm{Al}$ oxides free and amorphous) in the clay fraction (PARFITT, 1978; MATOS et al., 1996).
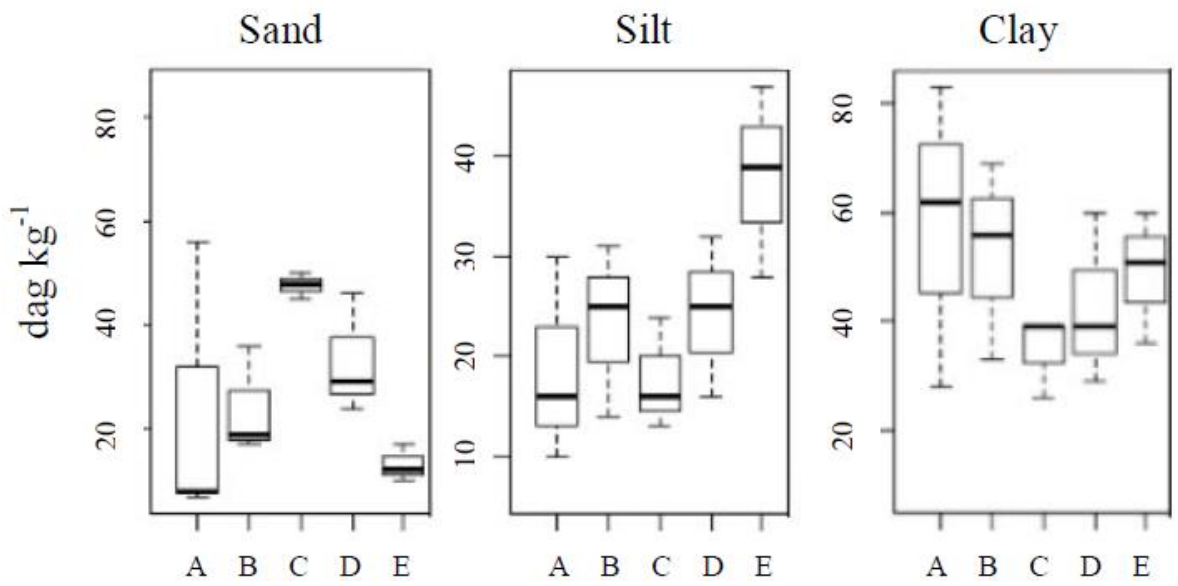

Fig. 1: Sand, silt and clay boxplot diagram in the five sample points (expressed in dag $\mathrm{kg}^{-1}$ )

Irrespective of point, Table 2 shows the average values found for each amount of lead added, $\mathrm{pH}$ and Tukey's statistical test.

Table 2: Results and statistical analysis of the amount of $\mathrm{Pb}$ found in the soils on different dosages e $\mathrm{pH}$

\begin{tabular}{|c|c|c|c|c|c|}
\hline $\begin{array}{c}\text { Doses of } \mathrm{Pb} \\
\text { added }\end{array}$ & $\begin{array}{l}\mathrm{Pb} \text { average } \\
\text { found }\end{array}$ & \multirow{2}{*}{$\begin{array}{c}\text { Tukey’s } \\
\text { statistical test }\end{array}$} & \multirow{3}{*}{$\begin{array}{c}\mathrm{pH} \\
\text { adjusted }\end{array}$} & $\mathrm{Pb}$ average found & \multirow{3}{*}{$\begin{array}{c}\text { Tukey's } \\
\text { statistical test }\end{array}$} \\
\hline \multicolumn{2}{|c|}{$\mathrm{mg} \mathrm{kg}^{-1}$} & & & & \\
\hline 0 & 42.22 & $\mathrm{c}$ & & mg kg & \\
\hline 50 & 180.84 & $\mathrm{cb}$ & 4.5 & 440.25 & $\mathrm{a}$ \\
\hline 100 & 276.77 & $\mathrm{~b}$ & 5.5 & 513.96 & $\mathrm{a}$ \\
\hline 500 & 1498.57 & $\mathrm{a}$ & 6.5 & 544.59 & $\mathrm{a}$ \\
\hline
\end{tabular}

Note: Means followed by the same letter do not differ by Tukey's statistical test at $5 \%$ level. 
Statistical differences were observed only among the treatments that received different doses of lead. Separately, there was no influence of $\mathrm{pH}$ on the amounts of lead adsorbed by soil. The highest values of lead found in the zero dose in relation to those found before the experiment are due to $\mathrm{pH}$ changes that increased the availability of lead. Table 3 shows the effect of the interaction between $\mathrm{pH}$ and different amounts of added lead.

Table 3. Mean values (expressed in $\mathrm{mg} \mathrm{kg}^{-1}$ ) and Tukey's statistical test of the interaction effects between $\mathrm{pH}$ and the levels of $\mathrm{Pb}$

\begin{tabular}{c|cc|cc|cc}
\hline $\begin{array}{c}\text { Doses of } \mathrm{Pb} \\
\text { added }\end{array}$ & $\mathrm{pH} 4.5$ & $\begin{array}{c}\text { Tukey's } \\
\text { statistical test }\end{array}$ & $\mathrm{pH} 5.5$ & $\begin{array}{c}\text { Tukey's } \\
\text { statistical test }\end{array}$ & $\mathrm{pH} 6.5$ & $\begin{array}{c}\text { Tukey's } \\
\text { statistical test }\end{array}$ \\
\hline 0 & 41.04 & $\mathrm{~b}$ & 34.92 & $\mathrm{~b}$ & 50.68 & $\mathrm{~b}$ \\
50 & 182.49 & $\mathrm{~b}$ & 171.74 & $\mathrm{~b}$ & 188.31 & $\mathrm{~b}$ \\
100 & 317.69 & $\mathrm{~b}$ & 219.85 & $\mathrm{~b}$ & 292.77 & $\mathrm{~b}$ \\
500 & 1219.75 & $\mathrm{a}$ & 1629.35 & $\mathrm{a}$ & 1646.60 & $\mathrm{a}$ \\
\hline
\end{tabular}

Note: Means followed by the same letter do not differ by Tukey's statistical test at $5 \%$ level.

Although the quantities of lead are adsorbed increased as the $\mathrm{pH}$ increased, it was observed that the interaction effects occurred only the dose of $500 \mathrm{mg} \mathrm{kg}^{-1}$ of lead nitrate. This shows that these soils, $\mathrm{pH}$ influence the adsorption of lead only in higher doses. From the results, the formulated following regression equation:

$$
Y=-2650+2.94 * D O S E+52.2 * p H
$$

where $\mathrm{Y}$ is the lead content in the soil samples $\left(\mathrm{mg} \mathrm{kg}^{-1}\right)$, DOSE corresponds to levels of lead which have been added $\left(0,50,100\right.$ or $\left.500 \mathrm{mg} \mathrm{kg}^{-1}\right)$ e $\mathrm{pH}$ corresponds to the three $\mathrm{pH}$ values studied $(4.5,5.5$ or 6.5). The high value of $\mathrm{R} 2(0.86)$ indicates a strong correlation between the values added to the vessels and between the adsorbed amounts, assigning a secondary role to the $\mathrm{pH}$ in smaller doses. Other authors papers (OLIVEIRA, 2008; CARVALHO, 1997) corroborate the results found in this study.

Table 4 shows the levels of lead extracted by the method previously described by Malavolta, Vitti and Oliveira (1997), fractionated in the aerial part of tomato crops. 
Table 4. Results and statistical analysis of the amount of $\mathrm{Pb}$ found in the aerial part on different dosages and $\mathrm{pH}$

\begin{tabular}{|c|c|c|c|c|c|}
\hline \multirow{2}{*}{$\begin{array}{c}\text { Doses of } \mathrm{Pb} \\
\text { added }\end{array}$} & $\mathrm{Pb}$ average found & Tukey’s & \multirow{3}{*}{$\begin{array}{c}\mathrm{pH} \\
\text { adjusted }\end{array}$} & $\mathrm{Pb}$ average found & \multirow{3}{*}{$\begin{array}{c}\text { Tukey's } \\
\text { statistical test }\end{array}$} \\
\hline & $\mathrm{mg} \mathrm{kg}^{-1}$ & istical test & & \multirow{2}{*}{$\mathrm{mg} \mathrm{kg}^{-1}$} & \\
\hline 0 & 22.99 & $\mathrm{~b}$ & & & \\
\hline 50 & 24.26 & $\mathrm{~b}$ & 5.5 & 25.07 & $\mathrm{a}$ \\
\hline 100 & 25.12 & $\mathrm{~b}$ & 4.5 & 29.02 & $\mathrm{a}$ \\
\hline 500 & 40.82 & $\mathrm{a}$ & 6.5 & 30.80 & $\mathrm{a}$ \\
\hline
\end{tabular}

Note: Means followed by the same letter do not differ by Tukey's statistical test at $5 \%$ level.

Analyzing the lead content in the aerial parts of tomatoes irrespective of points, was only observed statistical difference between the treatments of higher dose $\left(500 \mathrm{mg} \mathrm{kg}^{-1}\right)$. Separately, there was no influence of $\mathrm{pH}$ on the amounts of lead uptake. Table 5 shows the effect of the interaction in aerial part between $\mathrm{pH}$ and different amounts of added lead.

Table 5. Mean values (expressed in $\mathrm{mg} \mathrm{kg}^{-1}$ ) and Tukey's statistical test of the interaction effects between $\mathrm{pH}$ and the levels of $\mathrm{Pb}$

\begin{tabular}{c|cc|cc|cc}
\hline $\begin{array}{c}\text { Doses of Pb } \\
\text { added }\end{array}$ & pH 4.5 & $\begin{array}{c}\text { Tukey's } \\
\text { statistical test }\end{array}$ & pH 5.5 & $\begin{array}{c}\text { Tukey's } \\
\text { statistical test }\end{array}$ & pH 6.5 & $\begin{array}{c}\text { Tukey's } \\
\text { statistical test }\end{array}$ \\
\hline 0 & 22.80 & $\mathrm{~b}$ & 23.86 & $\mathrm{a}$ & 22.33 & $\mathrm{a}$ \\
50 & 25.33 & $\mathrm{~b}$ & 19.40 & $\mathrm{a}$ & 28.04 & $\mathrm{a}$ \\
100 & 20.72 & $\mathrm{~b}$ & 13.73 & $\mathrm{a}$ & 30.89 & $\mathrm{a}$ \\
500 & 47.24 & $\mathrm{a}$ & 33.28 & $\mathrm{a}$ & 41.92 & $\mathrm{a}$ \\
\hline
\end{tabular}

Note: Means followed by the same letter do not differ by Tukey’s statistical test at $5 \%$ level.

Significant amounts of lead in the aerial part of tomato, was only observed in the treatment of higher dose (500 $\mathrm{mg} \mathrm{kg}^{-1}$ ) and the more acid $\mathrm{pH}$ (4.5). By decreasing the $\mathrm{pH}$ of the soil also decreases the adsorption of the metal in soil and increases their concentration in the soil solution, thus increasing the uptake of metals by plants (GARBISU e ALKORTA, 2001). Moreover, some plants may also exude a variety of organic compounds forming complexes with metals and keeping them available for absorption (LASAT, 2000).

The results for $\mathrm{Pb}$ in the fruits are not shown, given that their concentrations were below the detection limit of the analytical method employed. However, it is possible to ensure that, if they had absorbed such element, this would present $\mathrm{Pb}<6.0 \mathrm{mg} \mathrm{kg}^{-1}$.

There was a higher accumulation of $\mathrm{Pb}$ in the aerial part, showing no translocation to the fruit, which to some extent was expected, as considerations of Malavolta (2006). According to the author, the $\mathrm{Pb}$ accumulates in the endoderm that acts as a partial barrier, and in the cell walls of the roots, and, in certain circumstances, they form amorphous precipitates identified as lead phosphate. 
Concurrently, Berton (1989) reports that, within the plant, some metals are concentrated in the roots and thus not are transported to the aerial part.

Also, at the soil, strong retention of $\mathrm{Pb}$ controls its availability, contrary to what happens, for example, with cadmium. The fact that $\mathrm{Pb}$ does not usually accumulate in fruits (GERHARDSSON, 2004) becomes another factor for lower concern with respect to this crop. Thus, the soil-plant system it is an important barrier for the entry of these metals in the food chain, which reduces problems with $\mathrm{Pb}$, for example.

\section{CONCLUSIONS}

The analysis of soils collected in five points the margin of Route MG-050 showed no signs of lead poisoning. The chemical characterization showed no abnormalities and small chemical variations in the attributes analyzed can be attributed to variations in texture and $\mathrm{pH}$. When these soils were subjected to different $\mathrm{pH}$ values According to the results of the experiment, the mobility of the $\mathrm{Pb}$ is low, indicating that this is not uptake directly from soil to plant parts, but from a microenvironment rich in organic matter, the lowest $\mathrm{pH}$, for the rhizosphere, which limits its translocation to aerial parts and fruits. This suggests that the most expressive concentrations may be found in the roots. Roots analyzes become essential to study the phytoavailability. The total content of metals into the soil is a poor indicator of the contamination of same and their toxicity to plants, since it rarely correlates with the concentration in plant tissues.

\section{ACKNOWLEDGEMENTS}

The authors thank the Foundation for Research Support of the State of Minas Gerais FAPEMIG - for the financial support, and also the chemical analysis laboratory of the department of metallurgical and materials engineering from the Federal University of Minas Gerais.

\section{REFERENCES}

ANDERSON, J. M.; INGRAM J.S. I. Tropical soil biology and fertility: a handbook of methods. CAB International, Wallingford, U.K. 1993.

CARVAlHO, O. A. Complexos de metais pesados com substâncias húmicas e matéria orgânica: estabilidade das ligações. In: Anais do II Encontro Brasileiro Sobre Substâncias Húmicas. São Carlos: EMBRAPA-CNPDIA. 1997, 72-93.

GARBISU, C.; ALKORTA, I. Phytoextraction: a cost effective plant-based technology for the removal of metals from the environment. Bioresource Technology, v. 77, p. $229-236,2001$.

GERHARDSSON, L. Lead. In: MERIAN, E.; ANKE, M.; IHNAT, M. \& STOEPPLER, M. Elements and their compounds in the environment. Weinheim: Verlag GmbH, 2nd, p. 879-900, 2004.

LASAT, M.M. Phytoextraction of metals from contaminated soil: a review of plant/soil/metal interaction and assessment of pertinent agronomic issues. Journal of Hazardous Substance Research, v.2, 25 p., 2000. 


\section{9 a 22 de outubro de 2014 \\ Florianópolis/SC}

LONG, X. X.; YANG X. E.; NI W. Z.; YE Z. Q.; HE Z. L.; CALVERT D. V.; J. P. STOFFELLA. Assessing zinc thresholds for phytotoxicity and potential dietary toxicity in selected vegetable crops. Commun Soil Sci. Plant Anal., v. 34(9-10), p. 1421-1434, 2010

MALAVOLTA, E. Elementos benéficos e tóxicos. Manual de nutrição mineral de plantas. São Paulo: Agronômica Ceres, p.418-511, 2006.

MALAVOLTA, E.; VITTI, G. C.; OLIVEIRA, S. A. Avaliação do estado nutricional das plantas princípios e aplicações. Piracicaba: POTAFÓS, 2. ed., 309 p, 1997.

MATOS, A. T., FONTES, M.P.F., JORDÃO, C.P., COSTA, L.M. Mobilidade e formas de retenção de metais pesados em latossolo vermelho-amarelo. Rev. Brasileira de Ciência do Solo, v. 20, p. 37986, 1996.

MCBRIDE, M. B. Reactions controlling heavy metal solubility in soils. Adv. Soil Sci., v. 10, p. 1-56, 1989.

NASER, H. M; SULTANA, S.; GOMES, R.; NOOR, S. Heavy metal pollution of soil and vegetable grown near roadside at Gazipur. Bangladesh J. Agril. Res. v. 37(1), p. 9-17, 2012.

OLIVEIRA, L. R. Metais pesados e atividade enzimática em Latossolos tratados com lodo de esgoto e cultivado com milho. Doctoral thesis. Jaboticabal: Unesp, 2008.

PARFITT, R. L. Anion adsorption by soils and soil materials. Adv. Agron., v. 30, p. 1-50, 1978.

RATTAN, R. K.; DATTAN S. P.; CHHONKAR P. K.; SURIBABU K.; SINGH A.K. Long-term impact of irrigation with sewage effluent on the heavy metal content in soil, crops and ground water. A case study. Agric. Ecosyst. Environ., v. 109, p. 310-322, 2005.

RIBEIRO, K. D.; MENEZES, S. M.; MESQUITA, M. da G. B. de F. Propriedades físicas do solo, influenciadas pela distribuição de poros, de seis classes de solos da região de Lavras-MG. Ciência $e$ Agrotecnologia. v. 31(4), p. 1167-1175, 2007.

SILVA, V. L.; CARVALHO, R.; FREITAS, M. P.; TORMENA, C. F.; MELO, W. C. Spectrometric and theoretical investigation of structures of $\mathrm{Cu}$ and Pb/DTPA complexes. Structural Chemistry, Deerfield Beach, v. 18, p. 605-609, 2007a.

SILVA, V. L.; CARVALHO, R.; FREITAS, M. P.; TORMENA, C. F.; MELO, W. C. Structural determination of $\mathrm{Zn}$ and Cd-DTPA complexes: MS, infrared, 13C NMR and theoretical investigation. Spectrochimica Acta, v. 68, p. 1197-1200, 2007 b.

SOBUKOLA, O. P.; ADENIRAN O. M.; ODEDAIRO A. A.; KAJIHAUSA O.E. Heavy metal levels of some fruit and leavy vegetables from selected markets in Lagos Nigeria. Afri. J. food Sci., v. 4(2), p. 389-393, 2003.

ZINN, Y. L.; LAL, R. \& RESCK, D.V.S. Texture and organic carbon relations described by a profile pedotransfer function for Brazilian Cerrado soils. Geoderma, v. 127, p. 168-173, 2005. 